\title{
EFFECTIVENESS OF BUSINESS TRANSFORMATION STRATEGY TO INCREASING COMPANY'S INCOME IN PRODUCTS DOOH (DIGITAL OUT OF HOME) IN PT. METRA DIGITAL MEDIA
}

\author{
Yitno Utomo $^{1}$, Rusdiyantoro ${ }^{2}$ \\ Program Studi Teknik Industri, Fakultas Teknologi Industri ${ }^{1,2}$ \\ Universitas PGRI Adi Buana Surabaya \\ email : yitnou@yahoo.com
}

\begin{abstract}
This reseach to study the effectiveness of business transformation strategy in PT Metra Digital Media and to know the difference increasing of company earnings in $\mathrm{DOOH}$ (Digital Out Of Home) product in PT Metra Digital Media, before and after implementation of business transformation strategy. The sample cases in this research are 22 customer companies that have not followed the business transformation process, which is advertised through the directory and control samples, and 22 customer companies that have been following the business transformation process are advertising through DOOH (Digital Out Of Home). Calculation data analysis using SPSS (Statistical Data Analysis) test that Independent-Samples T-Test. The results showed that the effectiveness of the implementation of business transformation strategy applies to product indicator, payment method, service and sales, because the OR (Odd Ratio) value is higher in companies that choose DOOH, while those that are not effectively selected are indicator of the period of exposure and popularity, the difference increasing of company earnings on DOOH (Digital Out Of Home) products at PT Metra Digital Media before and after the implementation of business transformation strategy is evidenced from $p=0,016$ ( $\mathrm{sig}$ $<0,05)$ and hypothesis is accepted.
\end{abstract}

Keywords: Business Transformation, Company Revenue

\section{INTRODUCTION}

PT Metra Digital Media (MD Media) is a subsidiary of PT. Telkom Metra, which was formed to manage advertising's business portfolio. PT. Elnusa establish make a product Yellow Pages which on June 20, 1980 officially as the owner of the publisher of the company owned by Telkom with the product name of BPT (Telephone Directory Book) and 2015 the company has to transform its portfolio into a portfolio of agencies, directories and integrated digital media.

Business transformation is to make fundamental strategic changes to overcome the shift in the market environment (Dirgantoro, 2002). Business transformation has been attempted to be carried out carefully by considering the steps to be taken in order to achieve the desired objectives. Bak'O., 2016 that the important things to be considered in business transformation are focus on benefits, teamwork building, sustainability and developing work skills Moran et al., 2000 that human resources is the most important subject in organizational to change efforts. The business transformation strategy must be start from change of paradigm of employees or human resources first, to know the potential of teamwork, to know the market position of our product and to control the product development in the future. The fundamental change of business today in the millennium era to the revolutionary age of the 4.0 industry is change of the digital

transformation. Stolterman et al., 2004 that the effects of digitalization require society to care for the system made by the technology world, its development will help people to work faster, wider and more accurate.

DOOH (Digital Out Of Home) which is subpart of IDM (Integrated Digital Media) product owned by PT. Metra Digital Media and DOOH (Digital Out Of Home) is a 
superior product in the form of advertising infrastructure. Considerations that need to be improved include the suitability of $\mathrm{DOOH}$ size and location is very important factor to get achievement of good visibility and accuracy in reaching the target audience, therefore need to review the design and location of existing $\mathrm{DOOH}$, besides it also evaluates the quality of lighting, the price offered and the advertisement.

Flaherty, 1996 mentions there are five things that must be done the company to get

The research begins by identifying a group of case subjects following business transformation and control subjects of companies willing to follow business transformation (DOOH advertisement). this research compared factor occurrences in the case group with the control group (Budiharto, 2008).

The sample cases in this research are 22 customer companies that have not followed the business transformation process, which is advertised through the directory and control samples in this research and 22 customer companies that have been following the business transformation process are advertising through DOOH (Digital Out Of Home). The variables of this research are products, payment patterns, delivery patterns, sales service and popularity. The dependent variable that will be used as a benchmark in viewing the success of this maximal income operational in restructuring, lowered operasinal cost, improved quality, continuous innovation and new product development, therefore this research to determine the effectiveness of business transformation strategy in PT Metra Digital Media as well as to know the difference of increase of company earnings on $\mathrm{DOOH}$ product (Digital Out Of Home) before and after the implementation of business transformation strategy.

\section{METHODS}

business transformation process is the change in corporate income.

Research data collection tool in the form of closed questionnaires and documentation used to see the number of purchases or transactions of companies that are revenue for the company under study. Data analysis using different Independent-Samples T-Test). The statistical measures used are Odds Ratio (OR) and 95\% CI(Confidence Interval)

\section{RESULT AND DISCUSSION}

The results of this research will present two main discussion about the effectiveness of business transformation strategy implementation and, hypothesis that there is difference of increase of company earnings on DOOH product (Digital Out Of Home) in PT Metra Digital Media before and after application of business transformation strategy. 


\section{Tibuana}

Journal of applied Industrial Engineering-University of PGRI Adi Buana

p-ISSN 2622-2027

$e$-ISSN 2622-2035

Table 1. Level of Effectiveness of the Application of Business

\begin{tabular}{|c|c|c|c|c|c|c|}
\hline \multirow{3}{*}{ Variabel } & \multicolumn{4}{|c|}{ Voters Company } & \multirow{4}{*}{ OR } & \multirow{4}{*}{$95 \% \mathrm{CI}$} \\
\hline & \multicolumn{2}{|c|}{$\begin{array}{c}\text { Case } \\
\text { (Directory) }\end{array}$} & \multicolumn{2}{|c|}{$\begin{array}{l}\text { Control } \\
\text { (DOOH) }\end{array}$} & & \\
\hline & $\mathbf{n}$ & $\%$ & n & $\%$ & & \\
\hline \multicolumn{5}{|l|}{ Product } & & \\
\hline Ineffective & 5 & $22,7 \%$ & 1 & $4,5 \%$ & 6,17 & $0,657-58,031$ \\
\hline Effective & 17 & $77,3 \%$ & 21 & $95,5 \%$ & & \\
\hline \multicolumn{7}{|l|}{$\begin{array}{l}\text { Payment } \\
\text { method }\end{array}$} \\
\hline Ineffective & 2 & $9,1 \%$ & 1 & $4,5 \%$ & 2,10 & $0,176-25,010$ \\
\hline Effective & 20 & $90,9 \%$ & 21 & $95,5 \%$ & & \\
\hline \multicolumn{7}{|l|}{ Viewing Period } \\
\hline Ineffective & 14 & $63,6 \%$ & 13 & $59,1 \%$ & 1,21 & $0,359-4,084$ \\
\hline Effective & 8 & $36,4 \%$ & 9 & $40,9 \%$ & & \\
\hline \multicolumn{7}{|l|}{ Service \& Sales } \\
\hline Ineffective & 13 & $59,1 \%$ & 4 & $18,2 \%$ & 6,50 & $1,640-25,759$ \\
\hline Effective & 9 & $40,9 \%$ & 16 & $81,8 \%$ & & \\
\hline \multicolumn{7}{|l|}{ Popularitas } \\
\hline Ineffective & 10 & $45,5 \%$ & 11 & $50,0 \%$ & 0,83 & $0,255-2,724$ \\
\hline Effective & 12 & $54,5 \%$ & 11 & $50,0 \%$ & & \\
\hline Total & 22 & $100 \%$ & 22 & $100 \%$ & & \\
\hline
\end{tabular}

The product indicator is very important because the value of $\mathrm{OR}=6.17(95 \% \mathrm{CI}$ $0.315<$ OR < 132.73) means DOOH product is more effective and is selected 6.17 times higher by consumers as a form of business transformation, indicator of payment method is very meaningful because the value of $\mathrm{OR}=$ $2.10(95 \%$ CI $0.176<\mathrm{OR}<25.010)$ means DOOH product is more effective and chosen Service and sales indicators are also significant because the value of $\mathrm{OR}=6.50$ (95\% CI $1.640<\mathrm{OR}<25,759)$ means DOOH products are more effective and selected 6.50 times higher by consumers as a form of business transformation, and popularity
2.10 times higher by consumer as a form of business transformation, correlation with delivery period, indicator of delivery period is not significant because the value of $\mathrm{OR}=$ 1.21 (95\% CI $0.359<\mathrm{OR}<4,084)$ means directory product more effective and selected equal to 1.21 times higher by consumers as being resisting business transformation.

Indicator is not significant because the value of $\mathrm{OR}=0.83(95 \%$ CI $0.255<\mathrm{OR}<2.724)$ means Directory products are more effective and selected by 0.83 times higher by consumers as those that resist business transformation. 


\section{Tibuana}

Journal of applied Industrial Engineering-University of PGRI Adi Buana

Table 2. Comparison of Company Revenues

\begin{tabular}{|c|c|c|c|c|c|c|c|}
\hline \multirow[b]{2}{*}{ No } & \multicolumn{3}{|c|}{ Cases (Directory) } & \multirow[b]{2}{*}{ No } & \multicolumn{3}{|c|}{ Control (DOOH) } \\
\hline & Company & Specialy & Venue & & Com pany & Specialy & Venue \\
\hline 1 & A neka Pompa Teknik Perkasa PT & Pumps & 15.463 .200 & 1 & Pancaputra Satriaw ib awa PT & Lubricants & 26.455 .200 \\
\hline 2 & A sia Repro CV & Printing Equipment & 11.484 .000 & 2 & Perkasa Teknika Utama CV & Tools & 14.179 .200 \\
\hline 3 & Bintang Chrom in do & Chrome & 21.556 .920 & 3 & Raja wali Permai Perkasa CV & Build ing $M$ aterials & 12.528 .000 \\
\hline 4 & Creatif $\mathrm{T}$ echnolog ies & Copying $M$ ach in es & 5.122 .440 & 4 & Sakura Makmur W ijaya PT & Supermarkets & 16.279 .200 \\
\hline 5 & Davind o Eka $S$ urya $P T$ & Plastics - Products & 12.734 .400 & 5 & Sariton Jaya CV & Build ing $M$ aterials & 15.066 .000 \\
\hline 6 & Delta Ja ya Mas PT & Hose & 7.404 .480 & 6 & Sekawan Cosmetics & Cosmetics - Distributors & 32.616 .000 \\
\hline 7 & Fit In ternation al T ailor & T ailors & 14.677 .200 & 7 & Surya In dah Perkasa CV & Pumps & 35.357 .400 \\
\hline 8 & G asek a PT & Hose & 72.999 .000 & 8 & Tanjung Baru UD & Packaging Service & 14.553 .600 \\
\hline 9 & G B T Laras Imbang & Tyre Equipment & 4.111 .560 & 9 & Trija ya A nu grah B in a Steel PT & Stainless & 18.904 .080 \\
\hline 10 & Gemilang Utama $\mathrm{K}$ oneks in do $\mathrm{PT}$ & Filters - A ir \& & 28.344 .000 & 10 & Wijay a Panca Sentosa Food PT & Food Products & 14.061 .600 \\
\hline 11 & Go Rent Scaffolding & Scaffolding & 14.664 .240 & 11 & Creatif Technolog ies & Copying s & 11.136 .000 \\
\hline 12 & $\mathrm{H}$ ouse $\mathrm{Of}$ In dogress & Build ing $M$ aterials & 27.996 .000 & 12 & Suryatama Mega Cemerlang PT & Plastics & 18.079 .200 \\
\hline 13 & Inoscco Surya Pratama PT & Lubricants & 11.832 .000 & 13 & Central Diesel PT & Generators & 41.082 .600 \\
\hline 14 & Iso E lek tra PT & Generators - & 20.246 .400 & 14 & Centraltekn in do A badiperkas a PT & Chains & 11.353 .680 \\
\hline 15 & Jatiwuni Persada CV & Contractors - & 7.987 .200 & 15 & Kalim as PT & Transport & 36.731 .880 \\
\hline 16 & Makassar M ega Prima PT & Furn iture $\mathrm{M}$ anu facturers & 15.594 .600 & 16 & Lomax PT & Packag ing Service & 35.540 .400 \\
\hline 17 & Megatitia $\mathrm{n}$ us antara PT & Transport - Cargo & 15.645 .120 & 17 & Telekom un ik asi Selular PT & Cellular-Services & 46.855 .200 \\
\hline 18 & Metro Interior Decoration & Wallpapers & 12.734 .400 & 18 & Central Diesel PT & Generators & 126.940 .320 \\
\hline 19 & $\mathrm{Multi \textrm {M } \text { as CV }}$ & Belting-Mechan ical & 21.836 .880 & 19 & Kalimas PT & Transport - Cargo & 56.210 .760 \\
\hline 20 & Multi Perkasa CV & Con tractors - General & 13.991 .280 & 20 & Lomax PT & Packag ing Service & 75.240 .000 \\
\hline 21 & Ngagel Jaya Konstruksi Baja & Con tractors - General & 12.528 .000 & 21 & Telekom un ik asi Selular PT & Telecommunication & 24.948 .000 \\
\hline \multirow[t]{3}{*}{22} & Niaga Tehnik & Hardware - Retail & 22.396 .800 & 22 & Bimasakti Multiweal th & Electronic Payment & 90.240 .000 \\
\hline & Total & & 391.350 .120 & & Total & & 774.358 .320 \\
\hline & M ean & & 17.788 .642 & & Mean & & 35.198 .105 \\
\hline
\end{tabular}

Average earnings of the company before doing business transformation (Directory customers) reached Rp.17.788.642 while the revenue of the company after doing business transformation (customer DOOH) reached Rp. 35.198.105, and t-test results using SPSS analysis can be show in table 3 .

Tabel 3. Independent Samples Test Results

Iderenuker Samplas Tost

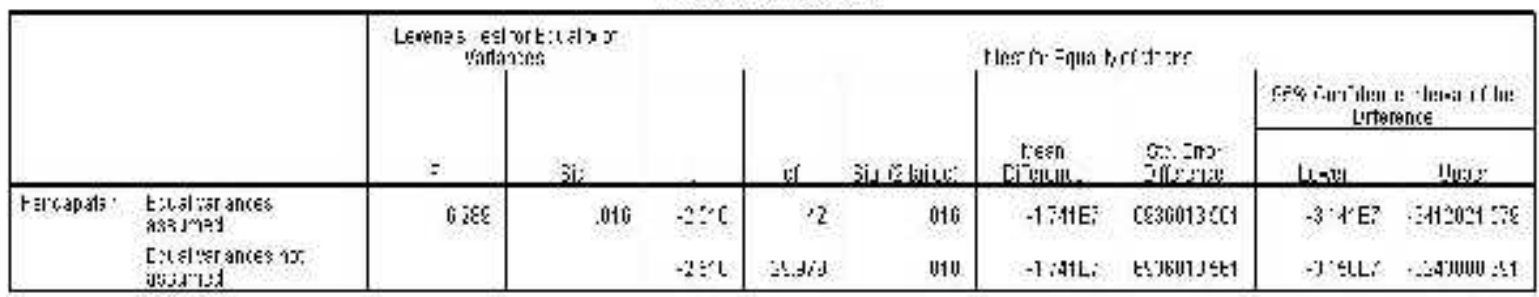

The test result is obtained $\mathrm{p}=0,016$ (sig $<0,05)$ this assumption shows that the research hypothesis $\mathrm{H} 1$ accepted and reject $\mathrm{H} 0$, there is difference to increase of company earnings in product DOOH (Digital Out Of Home) at PT Metra Digital Media before and after application business transformation strategy.

\section{CONCLUSION}

Based on data analysis, the research entitled Increasing Revenue Company On Products DOOH (Digital Out Of Home) at PT. Metra Digital Media can be summarized as follows:
1. Effectiveness of the implementation of business transformation strategy applies to product indicator, method of payment, service and sales because the OR value is higher in the company that choose $\mathrm{DOOH}$ while the ineffective one is chosen is the indicator of the period of viewing and the popularity

2. There is a difference between increase of company's revenue on $\mathrm{DOOH}$ product at PT Metra Digital Media before and after the implementation of business transformation strategy proved by $\mathrm{p}=0,016(\operatorname{sig}<0,05)$ 


\section{REFERENCES}

1. Bak, O. (2016). Investigating Organizational Transformation in Automotive Supply Chains: A Case Study on B2B and Extranet. Strategic Change, 25(3), 299-314.

2. Budiharto. (2008). Metodologi Penelitian Kesehatan dengan Contoh Bidang Ilmu Kesehatan Gigi. Jakarta: EGC.

3. Dirgantoro, Crown. (2002). Keunggulan Bersaing Melalui Proses Bisnis. Jakarta : PT. Gramedia Widisarana

4. Erik Stolterman, Anna Croon Fors. (2004), "Information Technology and

the Good Life", in: "Information systems research: relevant theory and informed practice", ISBN 1-40208094-8, p. 689

5. Flaherty, M.T. (1996). Global Operation Management, New York: Mc. Graw Hill, Inc

6. Moran, John W., Baird K. Brightman. (2000). Leading Organizational Change. Journal of Workplace Learning: Employee Conselling Today, Vol. 12. No. 2, pp 66-74 